Journal of Information System, Applied, Management, Accounting and Research.

http://journal.stmikjayakarta.ac.id/index.php/jisamar,

jisamar@stmikjayakarta.ac.id , jisamar2017@gmail.com

e-ISSN: 2598-8719 (Online), p-ISSN: 2598-800 ( Printed), Vol. 5 No.1 Februari 2021

\title{
PENGARUH RETURN ON EQUITY DAN DEBT TO EQUITY RATIO TERHADAP STOCK RETURN (Studi Kasus Pada Perusahaan Food and Beverages yang terdaftar di Bursa Efek Indonesia Periode 2014-2018)
}

\author{
Meirwan Nurcahya Dika', Muhammad Ikhsan Pratama, \\ Caswanto $^{3}$, Ismi Fajrianti ${ }^{4}$ \\ Program Studi S1 Akuntansi ${ }^{1}$, Program Studi S1 Akuntansi ${ }^{2}$, Program Studi S1 \\ Akuntansi ${ }^{3}$, Program Studi S1 Akuntansi ${ }^{4}$ \\ Fakultas Ekonomi ${ }^{1}$, Fakultas Ekonomi ${ }^{2}$, Fakultas Ekonomi ${ }^{3}$, Fakultas Ekonomi ${ }^{4}$ \\ Universitas Singaperbangsa Karawang ${ }^{1}$, Universitas Singaperbangsa Karawang ${ }^{2}$, \\ Universitas Singaperbangsa Karawang ${ }^{3}$, Universitas Singaperbangsa Karawang ${ }^{4}$ \\ Meirwannurcahyadika22@gmail.com ${ }^{1}, \underline{\text { Ikhsanpratama886@gmail.com }}{ }^{2}$
}

\begin{abstract}
Abstrak: Penelitian ini bertujuan untuk menguji pengaruh Return On Equity (ROE) dan Debt to Equity Ratio (DER) Terhadap Harga Saham Perusahaan Sektor Food and Beverages yang Terdaftar di Bursa Efek Indonesia. Data yang digunakan dalam penelitian ini adalah data sekunder yang bersumber dari data laporan keuangan peusahaan di Bursa Efek Indonesia. Populasi yang digunakan dalam penelitian ini adalah seluruh perusahaan sektor makanan dan minuman yang terdaftar di BEI. Penelitian ini menggunakan teknik purposive sampling dengan kriteria yang telah ditentukan. Jumlah sampel yang digunakan dalam penelitian ini sebanyak 7 perusahaan. Metode analisis yang digunakan adalah analisis regresi linear berganda. Hasil penelitian menunjukkan bahwa secara parsial Return On Equity (ROE) berpengaruh terhadap Stock Return dan Debt to Equity Ratio (DER) tidak berpengaruh terhadap Stock Return pada perusahaan food and beverages yang terdaftar di Bursa Efek Indonesia (BEI).
\end{abstract}

Kata Kunci : Return On Equity (ROE), Debt to Equity Ratio (DER), Stock Return

Abstract: This study aims to examine the effect of Return On Equity (ROE) and Debt to Equity Ratio (DER) on Stock Prices of Food and Beverages Sector Companies Listed on the Indonesia Stock Exchange. The data used in this research is secondary data which comes from the financial statements of companies on the Indonesia Stock Exchange. The population used in this study were all companies in the food and beverage sector listed on the IDX. This study uses purposive sampling technique with predetermined criteria. The number of samples used in this study were 7 companies. The analytical method used is multiple linear regression analysis. The results showed that partially Return On Equity (ROE) affects Stock Return and Debt to Equity Ratio (DER) has no effect on Stock Return on food and beverages companies listed on the Indonesia Stock Exchange (IDX).

Keywords : Return On Equity (ROE), Debt to Equity Ratio (DER), Stock Return

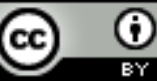

Ciptaan disebarluaskan di bawah Lisensi Creative Commons Atribusi 4.0 Internasional. 


\section{Journal of Information System, Applied, Management, Accounting and Research. http://journal.stmikjayakarta.ac.id/index.php/jisamar, jisamar@stmikjayakarta.ac.id, jisamar2017@gmail.com e-ISSN: 2598-8719 (Online), p-ISSN: 2598-800 ( Printed), Vol. 5 No.1 Februari 2021}

\section{PENDAHULUAN}

Bursa Efek Indonesia merupakan tempat perdagangan saham berbagai perusahaan Indonesia. Menurut departemen yang dikelola, semua jenis perusahaan tersebut dikelompokkan di Bursa Efek Indonesia. Sektor-sektor tersebut meliputi sektor pertanian, sektor pertambangan, sektor industri dasar dan kimia, sektor aneka industri, sektor industri barang konsumsi, sektor properti, sektor infrastruktur, sektor keuangan, dan sektor perdagangan dan jasa investasi. Investasi sebenarnya menyiapkan dana dalam jumlah besar saat ini untuk mendapatkan keuntungan di masa depan. Investasi sekuritas juga likuid (tidak stabil). Oleh karena itu, bagi suatu perusahaan selalu perlu untuk fokus pada kepentingan perusahaan dengan cara memaksimalkan keuntungan perusahaan, dan kepentingan pemilik modal dengan cara memaksimalkan nilai perusahaan, karena nilai perusahaan merupakan tolak ukur keberhasilan fungsi keuangannya.

Kondisi kurang menguntungkan yang dialami perseroan telah membawa perekonomian dunia ke babak baru, runtuhnya stabilitas global, yang sejalan dengan merebaknya krisis keuangan di berbagai negara. Sejak Dana Moneter Internasional menurunkan perkiraan pertumbuhan ekonomi sebagian besar negara di dunia pada Juli 2019, krisis keuangan global mulai muncul.

Dampak krisis keuangan melanda seluruh sektor Bursa Efek Indonesia, terutama perusahaan makanan dan minuman, dimana investor terancam oleh situasi ini sehingga mereka mengalami aksi jual besar-besaran yang menyebabkan harga saham turun. Penurunan harga saham telah menyebabkan penurunan return saham bagi investor.

Adanya pertumbuhan ROE menunjukkan peluang perusahaan yang semakin baik karena berarti adanya kapasitas peningkatan keuntungan yang diperoleh perusahaan [1]

Menurut Hanafi, rasio ini digunakan untuk menilai profitabilitas perusahaan. Kinerja keuangan diukur dengan menggunakan rasio profitabilitas sebagai indikator pengukuran yaitu return on equity (ROE), sedangkan struktur modal diukur dengan menggunakan rasio solvabilitas yaitu debt-to-equity ratio (DER), debt-to-asset ratio (DAR), hutang jangka panjang aktiva. Rasio (LDAR) dan rasio hutang terhadap ekuitas (LDER) jangka panjang. Dari perspektif pemegang saham, pengembalian ekuitas adalah ukuran profitabilitas.[2]. ROE adalah perbandingan antara laba bersih dan ekuitas. Pengembalian ekuitas yang tinggi menunjukkan tingkat profitabilitas yang tinggi [2].

Penelitian sebelumnya (yaitu penelitian yang dilakukan Nurmasari) menunjukkan bahwa current ratio (CR), return on equity (ROE), debt to equity ratio (DER) dan pertumbuhan pendapatan tidak berpengaruh signifikan terhadap return saham (RS) [3]. Kampongsina menunjukkan bahwa current ratio (CR), return on equity (ROE) dan debt-to-equity ratio (DER) tidak berpengaruh signifikan terhadap return saham.[4].

Namun, mengenai pengumuman UMA ini tidak serta-merta menunjukkan adanya pelanggaran terhadap peraturan perundang-undangan di bidang pasar modal. Pola transaksi perdagangan saham ALTO sudah mengalami peningkatan sejak Agustus lalu. Kala itu saham perseroan diperdagangkan di angka Rp 238 per saham, kemudian terus merangkak naik hingga akhirnya menembus angka Rp 580 pada perdagangan saham. Artinya, perdagangan saham perusahaan sudah mengalami peningkatan lebih dari 100\% sejak 3 bulan lalu[5]

\section{METODE DAN MATERI}

\section{LANDASAN TEORI}

Stock Return

Menurut Fahmi, Stock return adalah sebagai berikut: "Stock Return adalah keuntungan yang diharapkan oleh investor dimasa depan dari jumlah modal yang diinvestasikan. Ekspektasi menggambarkan apa yang mungkin terjadi di luar kisaran yang diharapkan." [6]

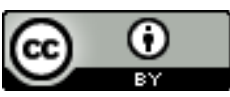

Ciptaan disebarluaskan di bawah Lisensi Creative Commons Atribusi 4.0 Internasional. 


\section{Journal of Information System, Applied, Management, Accounting and Research. http://journal.stmikjayakarta.ac.id/index.php/jisamar, jisamar@stmikjayakarta.ac.id, jisamar2017@gmail.com e-ISSN: 2598-8719 (Online), p-ISSN: 2598-800 ( Printed), Vol. 5 No.1 Februari 2021}

Return realisasi sangat penting karena dapat digunakan sebagai salah satu pengukur kinerja perusahaan.[7]. Return Ekspektasi (expected return) merupakan return yang digunakan untuk pengambilan keputusan investasi. Return ini penting dibandingkan dengan return historis [7]. Stock Return terdiri dari capital gain dan dividen yield. Capital gain adalah selisih antara harga jual dan harga beli saham per lembar dibagi dengan harga beli, dan dividen yield adalah dividen per lembar dibagi dengan harga saham per lembar [8]. Menurut Tandelilin, stock return mencakup dua bagian yaitu capital gain (kerugian) dan keuntungan. Capital gain (kerugian) mengacu pada kenaikan (penurunan) harga saham yang dapat membawa keuntungan (kerugian) bagi investor [9]. Laba merupakan komponen pengembalian yang mencerminkan arus kas atau pendapatan yang diterima dari investasi saham secara berkala.

Menurut Jogiyanto, stock return dibagi menjadi dua bagian yaitu realisasi (realized return) dan return yang diharapkan. [10]

Return On Equity

Return on equity (ROE) adalah ukuran kemampuan perusahaan menggunakan total modalnya untuk menciptakan keuntungan bagi pemegang saham. Rasio ini menunjukkan penggunaan modal sendiri secara efektif. Semakin tinggi rasionya maka semakin kuat pula posisi pemilik perusahaan, begitu pula sebaliknya [11].

Return on equity sangat penting bagi pemegang saham dan calon investor, karena return on equity yang tinggi berarti pemegang saham akan menerima deviden yang tinggi, dan peningkatan return on equity akan berujung pada peningkatan saham.[12]

Debt to Equity Ratio (DER)

Agnes meyakini bahwa debt ratio atau debt ratio menunjukkan rasio utang terhadap seluruh aset yang dimiliki. [13]. Berdasarkan uraian di atas dapat disimpulkan bahwa debt to equity ratio merupakan rasio antara total utang dan total aset

\section{METODE PENELITIAN}

Metode penelitian pada dasarnya adalah metode ilmiah untuk memperoleh data untuk tujuan dan kegunaan tertentu. Metode ilmiah didasarkan pada ciri-ciri keilmuan yaitu rasional, empiris dan sistematis. Rasionalitas artinya kegiatan penelitian dilakukan dengan cara yang bermakna sehingga nalar manusia dapat terjangkau. Pengalaman berarti cara indera manusia mengamatinya. Pendekatan sistematis adalah proses yang digunakan dalam penelitian menggunakan langkah-langkah logis tertentu.[14]

Dalam penelitian ini, penulis menggunakan metode kuantitatif dengan pendekatan deskriptif verifikatif. Metode kuantitatif menurut Creswell dalam Trijono penelitian kuantitatif yaitu : "Penyelidikan tentang masalah kemasyarakatan atau kemanusiaan yang didasarkan pada pengujian suatu teori yang tersusun atas variabel-variabel, diukur dengan bilangan-bilangan, dan dianalisis dengan prosedur-prosedur statistik”. [15]

Sugiyono mengemukakan bahwa metode deskriptif adalah "melakukan penelitian untuk mengetahui keberadaan variabel bebas, variabel bebas tersebut dapat berupa satu atau lebih variabel tanpa ada pembanding atau perbandingan dengan variabel lain (variabel bebas)" [14]. Sedangkan metode verifikasi yang dikemukakan sugiyono adalah "metode penelitian yang dirancang untuk mengetahui hubungan sebab akibat antar variabel melalui uji statistik yang menunjukkan bahwa hipotesis ditolak atau diterima"[14].

\section{VARIABEL PENELITIAN}

Definisi Konseptual

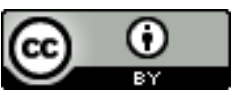

Ciptaan disebarluaskan di bawah Lisensi Creative Commons Atribusi 4.0 Internasional. 


\section{Journal of Information System, Applied, Management, Accounting and Research. http://journal.stmikjayakarta.ac.id/index.php/jisamar, jisamar@stmikjayakarta.ac.id , jisamar2017@gmail.com e-ISSN: 2598-8719 (Online), p-ISSN: 2598-800 ( Printed), Vol. 5 No.1 Februari 2021}

Menurut Hatch dan Farhady (Sugiyono,2015) variabel adalah atribut atau objek dan terdapat perbedaan di antara keduanya. Dalam penelitian ini identifikasi variabel digunakan untuk membantu menentukan alat pengumpulan data dan teknis analisis data yang digunakan.[14]

Return On Equity

Menurut Kasmir, Return on equity (ROE) adalah gunakan modal sendiri untuk mengukur rasio laba bersih setelah pajak. Rasio ini menunjukkan penggunaan modal sendiri secara efektif. Semakin tinggi rasionya, semakin baik. Artinya posisi pemilik perusahaan semakin kuat, begitu pula sebaliknya semakin rendah rasionya maka perusahaan semakin lemah. [11]

Debt to Equity Ratio (DER)

Menurut Kasmir, Debt-to-equity ratio adalah rasio yang digunakan untuk menilai debt-to-equity. Temukan rasio ini dengan membandingkan semua hutang (termasuk hutang saat ini) dan ekuitas total. Rasio ini digunakan untuk menentukan jumlah dana yang disediakan oleh peminjam (kreditur) dan pemilik perusahaan. Atau bisa dikatakan bahwa rasio ini membantu mencari modal sendiri dari setiap rupee yang digunakan sebagai jaminan hutang. [11]

\section{Stock Return}

Menurut Jogiyanto, Stock Return adalah tingkat keuntungan yang dinikmati investor dalam investasinya. Jenis pendapatan yang digunakan dalam penelitian ini adalah pendapatan realisasi atau yang biasa disebut pendapatan aktual yaitu pendapatan modal, yaitu selisih harga saham periode berjalan dengan harga saham periode sebelumnya dibagi harga saham periode sebelumnya. Pengembalian aktual setiap saham selama acara tersebut. [10]

Instrumen Penelitian

Pada prinsipnya penelitian adalah pengukuran, sehingga harus ada alat ukur yang baik. Menurut Sugiyono instrumen penelitian adalah alat untuk mengukur fenomena alam dan sosial yang diamati. Dalam studi ini, pengaruh return ekuitas dan debt-to-equity ratio terhadap return saham dipelajari. [14]

Populasi

Populasi adalah seluruh objek penelitian. Menurut Sugiyono, populasi adalah suatu wilayah yang digeneralisasikan yang meliputi: objek / tema dengan kualitas dan karakteristik tertentu, objek / tema tersebut ditentukan oleh peneliti untuk melakukan penelitian dan kemudian menarik kesimpulan. [14]

Sampel

Menurut Sugiyono, Sampel merupakan bagian dari ukuran dan karakteristik populasi [14]. Sampel penelitian diperoleh melalui purposive sampling, karena perusahaan perbankan disini dapat memberikan informasi yang dibutuhkan untuk penelitian tersebut, dan jika memenuhi syarat tertentu maka sampel tersebut digunakan sebagai sampel.

Menurut Sugiyono, Teknik sampling merupakan teknik pengambilan sampel untuk menentukan sampel yang akan digunakan dalam penelitian, terdapat beberapa teknik sampling yang digunakan.[14]

Metode Analisis Data

Uji Normalitas

Menurut Sudarmanto, salah satu syarat pengujian yang harus dipenuhi menggunakan analisis parametrik adalah uji normalitas data secara keseluruhan. [16]

Uji normalitas dirancang untuk menguji apakah variabel dependen dan variabel independen dalam model regresi linier berdistribusi normal [17]

Uji Multikolinearitas

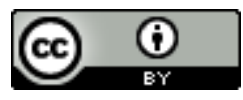

Ciptaan disebarluaskan di bawah Lisensi Creative Commons Atribusi 4.0 Internasional. 


\section{Journal of Information System, Applied, Management, Accounting and Research. http://journal.stmikjayakarta.ac.id/index.php/iisamar, jisamar@stmikjayakarta.ac.id , jisamar2017@gmail.com e-ISSN: 2598-8719 (Online), p-ISSN: 2598-800 ( Printed), Vol. 5 No.1 Februari 2021}

Menurut Sudarmanto, pengujian hipotesis multikolinearitas bertujuan untuk membuktikan atau menguji ada tidaknya hubungan linier antara satu variabel bebas dengan variabel bebas lainnya. [16]

Uji Autokorelasi

Menurut Sudarmanto, autokorelasi adalah korelasi antara anggota sekuens pengamatan yang disusun menurut deret waktu (seperti deret waktu) atau posisi / deret spasial (data cross-sectional), atau korelasi yang ditimbulkan sendiri. [16]

Autokorelasi bertujuan untuk menguji apakah terdapat korelasi antara kesalahan periode $\mathrm{T}$ dan $\mathrm{T}-1$ (sebelum) dalam model regresi linier, jika terdapat korelasi disebut masalah autokorelasi.[17]

Uji Heteroskedastisitas

Menurut Sudarmanto, pengujian hipotesis heteroskedastisitas bertujuan untuk mengetahui apakah perubahan residual absolut dari semua pengamatan adalah sama. [16]

Menurut Ghazali, Uji heteroskedastisitas bertujuan untuk menguji ada tidaknya varians yang tidak merata pada residual dari satu pengamatan ke pengamatan lainnya dalam model regresi. [17] Hasil dari heteroskedastisitas dalam model regresi adalah sebesar apapun sampelnya, nilai perkiraannya tidak valid.Salah satu metode yang dapat digunakan untuk mengetahui ada tidaknya gejala heteroskedastisitas adalah dengan melihat scatter plot. Adanya pola tertentu (seperti titik-titik) yang membentuk pola teratur tertentu (bentuk gelombang, melebar kemudian menyempit), hal ini menandakan telah terjadi heteroskedastisitas. Jika tidak ada pola yang jelas, tidak akan ada gejala heteroskedastisitas. Untuk mengetahui ada tidaknya heteroskedastisitas juga dapat ditentukan dengan melakukan uji Glejser. Jika variabel independen signifikan secara statistik dalam mempengaruhi variabel dependen menunjukkan adanya heteroskedastisitas [17]

Teknik Analisis Data

Menurut Sugiyono teknologi analisis data merupakan suatu kegiatan yang dilakukan setelah mengumpulkan data dari seluruh responden atau sumber data lainnya.[14]. Kegiatan dalam analisis data meliputi: pengelompokan data berdasarkan variabel dan jenis responden; membuat tabulasi data berdasarkan variabel dari semua responden; menampilkan data untuk setiap variabel penelitian; melakukan perhitungan untuk menjawab rumus pertanyaan; Rumus untuk melakukan penghitungan untuk menjawab pertanyaan; dan metode untuk melakukan penghitungan untuk menguji hipotesis telah diusulkan.

Analisis Regresi Linier Berganda

Analisis regresi linier berganda (multivariate random analysis) merupakan teknik multivariat yang sering digunakan dalam penelitian bisnis.Teknik ini menggunakan beberapa variabel independen untuk menjelaskan varians pada variabel dependen. Menurut Sekaran dan Bougie, titik awal analisis regresi berganda adalah model konseptual (dan asumsi model) yang dibuat oleh peneliti pada tahap awal proses penelitian. [18]

Berikut ini persamaan regresi linear berganda [17]

Dimana:

$$
\mathrm{Y}=\alpha+\mathrm{b}_{1} \mathrm{X}_{1}+\mathrm{b}_{2} \mathrm{X}_{2}+\mathrm{e}
$$

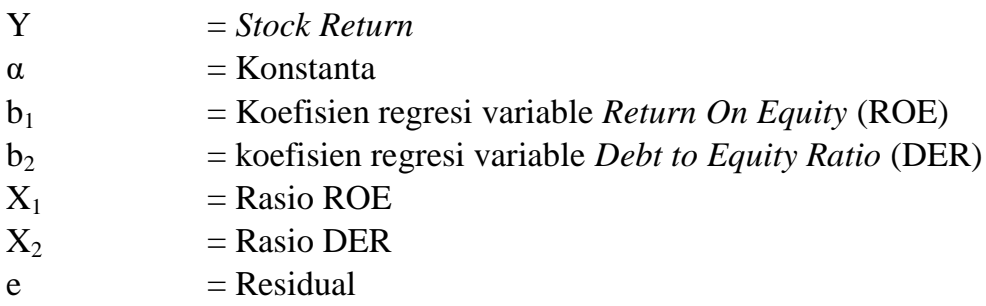

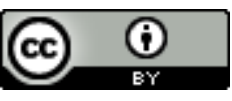

Ciptaan disebarluaskan di bawah Lisensi Creative Commons Atribusi 4.0 Internasional. 
Journal of Information System, Applied, Management, Accounting and Research.

http://journal.stmikjayakarta.ac.id/index.php/iisamar,

jisamar@stmikjayakarta.ac.id, jisamar2017@gmail.com

e-ISSN: 2598-8719 (Online), p-ISSN: 2598-800 ( Printed), Vol. 5 No.1 Februari 2021

\section{PEMBAHASAN DAN HASIL}

HASIL PENELITIAN

Statistik deskriptif memberikan penjelasan mengenai nilai minimum, nilai maksimum, nilai keseluruhan, nilai rata-rata (mean) dan standar deviasi dari keseluruhan data variabel independen dan variabel dependen. Dengan bantuan software SPSS 16 diperoleh hasil analisis statistik deskriptif sebagai berikut :

Tabel 1

Hasil Analisis Statistik Deskriptif

Descriptive Statistics

\begin{tabular}{|l|l|l|l|l|l|l|}
\hline & $\mathrm{N}$ & Minimum & Maximum & Sum & Mean & Std. Deviation \\
\hline ROE (X1) & 30 & 4.48 & 37.68 & 512.29 & 17.0763 & 7.05608 \\
DER (X2) & 30 & .17 & 1.51 & 20.38 & .6793 & .42817 \\
Stock Return (Y) & 30 & -.55 & 1.00 & 4.98 & .1660 & .30405 \\
Valid N (listwise) & 30 & & & & & \\
\hline
\end{tabular}

Sumbe

$r$ : Data

diolah

oleh

caswanto,

2020

(SPSS 16).

Berdasark

an tabel

4.2 dapat

dijelaskan beberapa hal sebagai berikut :

1. Nilai $\mathrm{N}$ yaitu 30. Artinya data yang digunakan dalam penelitian ini sebanyak 30 data atau dari 6 perusahaan selama periode 2014-2018. Di mana total dari populasi perusahaan berjumlah 18 perusahaan selama periode 2014-2018. Data tersebut berasal dari laporan keuangan tahunan perusahaan yang terdaftar pada Bursa Efek Indonesia (BEI) selama periode 2014-2018.

2. Return On Equity berdasarkan hasil pengolahan data, diperoleh nilai minimum sebesar 4.48, nilai maksimum sebesar 37.68, nilai keseluruhan sebesar 512.29, nilai rata-rata (mean) sebesar 17.0763 dan nilai standar deviasi sebesar 7.05608.

3. Debt to Equity Rasio berdasarkan hasil pengolahan data, diperoleh nilai minimum sebesar 0.17, nilai maksimum sebesar 1.51, nilai keseluruhan sebesar 20.38, nilai rata-rata (mean) sebesar 0.6793 dan nilai standar deviasi sebesar 0.42817 .

4. Stock Return berdasarkan hasil pengolahan data, diperoleh nilai minimum sebesar -0.55 , nilai maksimum sebesar 1.00, nilai keseluruhan sebesar 4.98, nilai rata-rata (mean) sebesar 0.1660 dan standar deviasi sebesar 0.30405 .

Uji Asumsi Klasik

Uji Normalitas

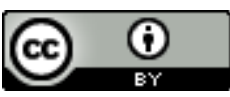

Ciptaan disebarluaskan di bawah Lisensi Creative Commons Atribusi 4.0 Internasional. 
Uji normalitas bertujuan untuk mengetahui apakah data berdistribusi normal atau tidak. Uji normalitas ini penting agar data yang digunakan merupakan data yang baik sehingga menghasilkan nilai yang akurat. Uji statistik yang digunakan untuk menguji apakah residual berdistribusi normal atau tidak adalah uji statistik non parametric Kolmogorov-smirnov (K-S). Kriteria pengambilan keputusan dalam uji normalitas, suatu data dapat dikatakan berdistribusi normal apabila nilai signifikasi $>0,05$ dan sebaliknya apabila signifikasi $<0,05$ maka data yang digunakan untuk penelitian tidak berdistribusi normal. Pengujian normalitas data, dibantu dengan bantuan SPSS 16, ditabulasikan sebagai berikut:

\section{Tabel 2}

Hasil Uji Normalitas

Data

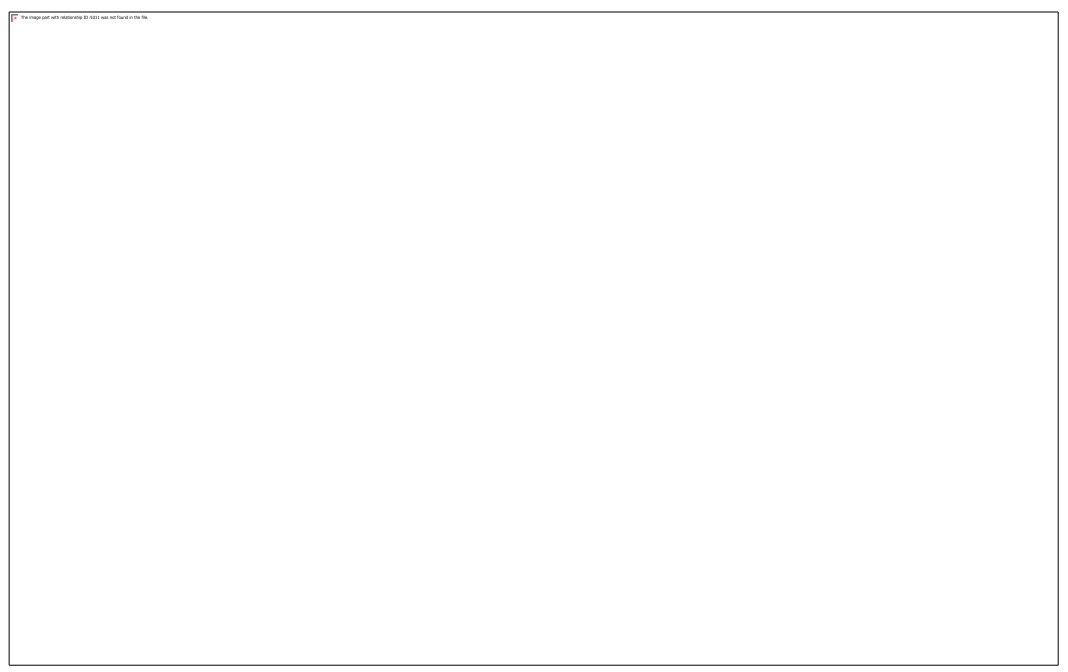

Sumber : Data diolah oleh caswanto, 2020 (SPSS 16).

Dari Tabel 4.3 dapat dilihat bahwa hasil dari pengujian one-sample kolmogorov-smirnov diperoleh nilai signifikasi sebesar 0927. Hal tersebut menunjukkan nilai signifikasi Komolgrov Smirnov lebih besar dari tingkat kesalahan atau alfa 5\% yaitu $0.927>0,05$. Maka dapat disimpulkan bahwa data yang digunakan dalam penelitian ini terdistribusi secara normal.

\section{Uji Multikolinieritas}

Uji multikolinieritas bertujuan untuk menguji apakah model regresi ditemukan adanya korelasi antar variabel bebas (Independen). Model regresi yang baik sebaiknya tidak terjadi korelasi di antara variabel independen. Jika terjadi multikolinieritas pada model regresi, maka koefisien regresi tidak dapat ditaksir dan nilai standard eror menjadi tidak terhingga. Uji Multikolinearitas dapat dilakukan dengan melakukan uji korelasi antara variabel independen dengan menggunakan tolerance dan varians inflating factor (VIF). Nilai cut off yang umum dipakai untuk menunjukkan adanya multikolinieritas adalah nilai tolerance $\leq 0,10$ dan varians inflating factor (VIF) 110.

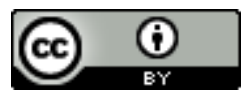

Ciptaan disebarluaskan di bawah Lisensi Creative Commons Atribusi 4.0 Internasional. 
Journal of Information System, Applied, Management, Accounting and Research.

http://journal.stmikjayakarta.ac.id/index.php/iisamar,

jisamar@stmikjayakarta.ac.id, jisamar2017@gmail.com

e-ISSN: 2598-8719 (Online), p-ISSN: 2598-800 ( Printed), Vol. 5 No.1 Februari 2021

Tabel 3

Hasil Uji Multikolinearitas

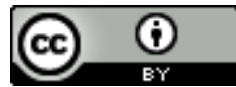

Ciptaan disebarluaskan di bawah Lisensi Creative Commons Atribusi 4.0 Internasional. 
Journal of Information System, Applied, Management, Accounting and Research.

http://journal.stmikjayakarta.ac.id/index.php/iisamar,

jisamar@stmikjayakarta.ac.id, jisamar2017@gmail.com

e-ISSN: 2598-8719 (Online), p-ISSN: 2598-800 ( Printed), Vol. 5 No.1 Februari 2021

Coefficients $^{\mathrm{a}}$

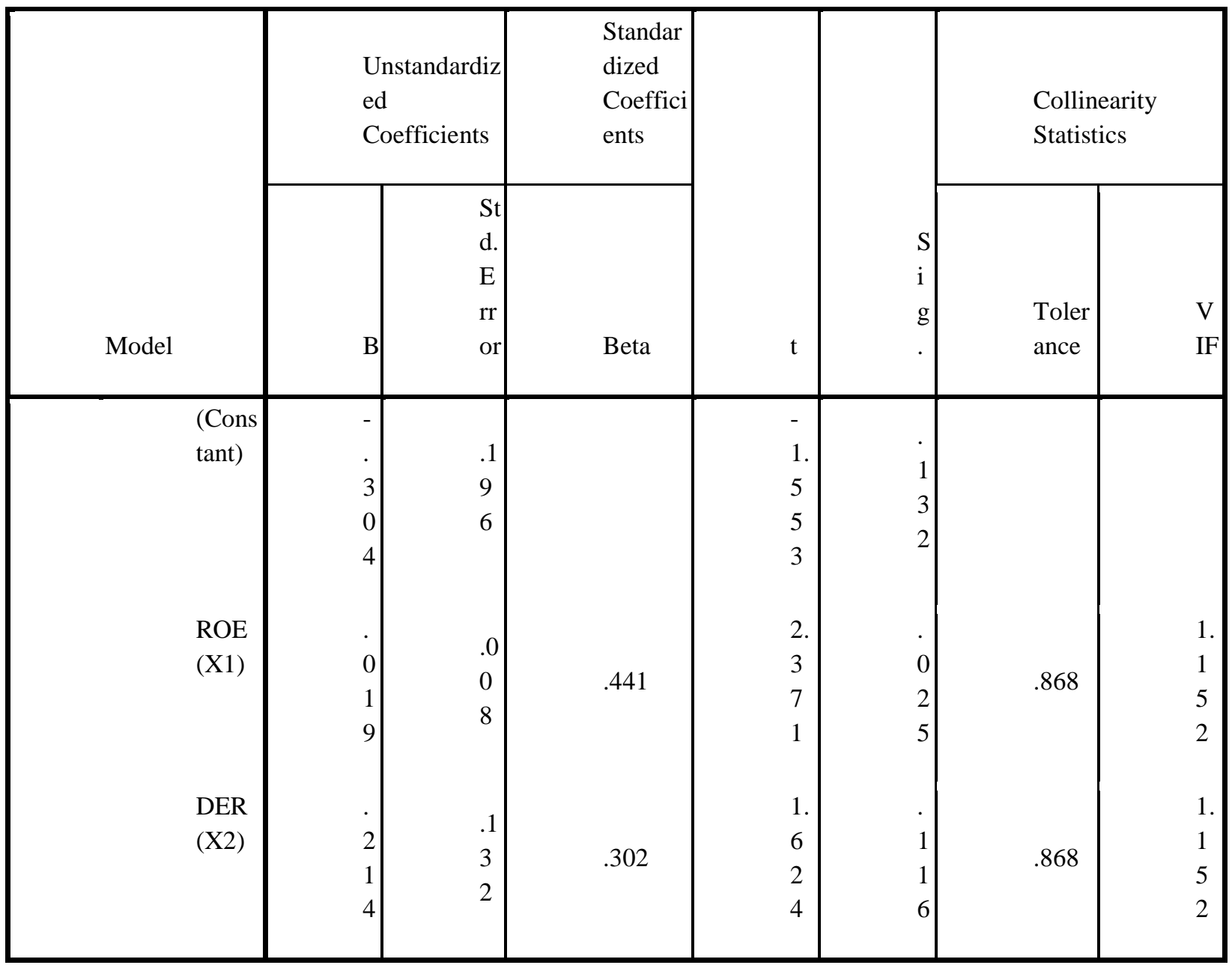

a. Dependent Variable: Stock Return

$(\mathrm{Y})$

Sumber : Data diolah oleh caswanto, 2020 (SPSS 16).

Dari data pada tabel 4.4, diperoleh nilai VIF hitung kedua variabel sebesar 1.152 dan berada di antara nilai 1-10. Nilai tolerance variabel bebas sebesar 0.868 lebih besar dari 0,10. Dengan demikian, dapat dikatakan bahwa data variabel bebas tidak terjadi gejala multikolinieritas.

\section{Uji Autokorelasi}

Uji autokorelasi bertujuan untuk menguji apakah dalam model regresi linier ada korelasi antara kesalahan variabel pengganggu pada suatu periode tertentu dengan periode sebelumnya dalam model regresi. Uji autokorelasi dapat

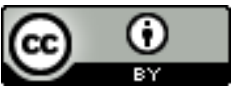

Ciptaan disebarluaskan di bawah Lisensi Creative Commons Atribusi 4.0 Internasional. 
dilakukan dengan metode uji Durbin Watson (DW Test), Run Test, ataupun uji Cochrane Orcutt. Dalam penelitian ini metode yang akan digunakan adalah Run Test. Dengan ketentuan Jika nilai Asymp. Sig. (2-tailed) lebih besar > dari 0.05 maka tidak terdapat gejala autokorelasi.

\section{Tabel 4}

\section{Uji Autokorelasi}

\section{Runs Test}

\begin{tabular}{|l|l|}
\hline & $\begin{array}{l}\text { Unstandardized } \\
\text { Residual }\end{array}$ \\
\hline Test Value ${ }^{\mathrm{a}}$ & -.00364 \\
Cases < Test Value & 15 \\
Cases >= Test Value & 15 \\
Total Cases & 30 \\
Number of Runs & 17 \\
Z & .186 \\
Asymp. Sig. (2-tailed) & .853 \\
\hline
\end{tabular}

a. Median

Sumber : Data diolah oleh caswanto, 2020 (SPSS 16).

Berdasarkan hasil pengujian di tabel 4.5, diperoleh nilai Asymp. Sig. (2-tailed) yaitu sebesar 0.853. Nilai 0.853 lebih besar dari 0.05 artinya pada model regresi penelitian ini tidak terdapat gejala autokorelasi atau terbebas dari autokorelasi.

\section{Uji Heteroskedastisitas}

Uji heteroskedastisitas bertujuan untuk menguji apakah dalam model regresi terjadi ketidaksamaan variance dari residual satu pengamatan kepengamatan yang lain. Model regresi yang baik adalah tidak terjadi heteroskedastisitas. Cara memprediksi ada atau tidaknya heteroskedastisitas pada suatu model regresi dengan dilihat melalui grafik plot antara nilai prediksi variabel terikat (dependen) yaitu ZPRED dengan residualnya yaitu SRESID. Dasar pengambilan keputusannya adalah sebagai berikut :

1) Jika ada pola tertentu, seperti titik-titik yang ada membentuk pola tertentu yang teratur (bergelombang, melebar kemudian menyempit), maka mengindikasikan telah terjadi heteroskedastisitas.

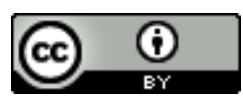

Ciptaan disebarluaskan di bawah Lisensi Creative Commons Atribusi 4.0 Internasional. 
2) Jika tidak ada pola yang jelas, serta titik-titik menyebar diatas dan dibawah angka 0 pada sumbu $\mathrm{Y}$, maka tidak terjadi heteroskedastisitas.

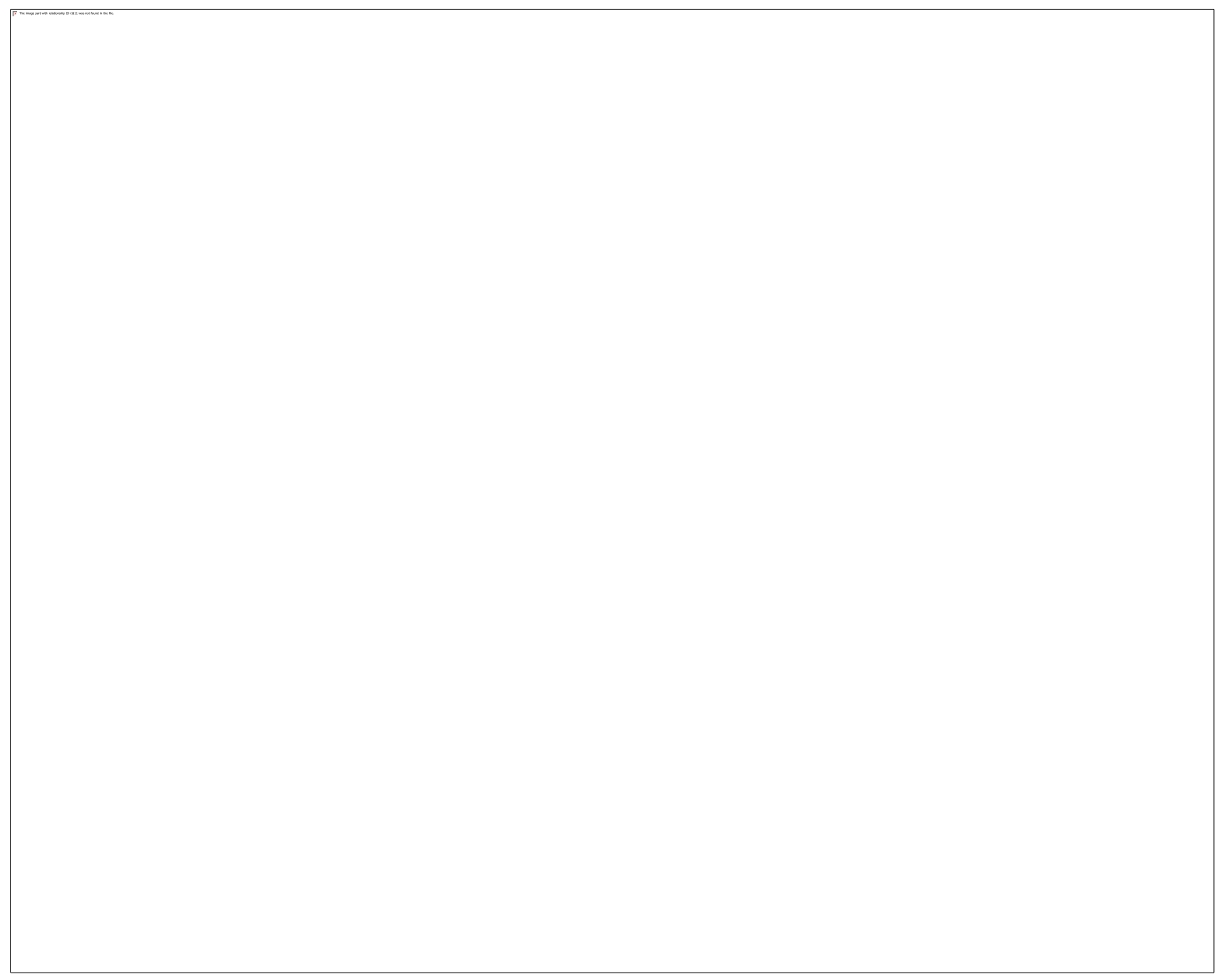

\section{Gambar 1}

\section{Hasil Uji Heteroskedastisitas (Scatterplot)}

Sumber : Data diolah oleh caswanto, 2020 (SPSS 16).

Dari gambar scatterplot pada gambar 4.1. Dapat dilihat, bahwa titik-titik menyebar secara acak serta tersebar baik di atas maupun di bawah angka 0 pada sumbu Y. Hasil ini dapat disimpulkan bahwa tidak terjadi heteroskedastisitas pada model regresi sehingga layak dipakai untuk memprediksi Stock Return pada perusahaan

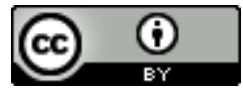

Ciptaan disebarluaskan di bawah Lisensi Creative Commons Atribusi 4.0 Internasional. 
Journal of Information System, Applied, Management, Accounting and Research.

http://journal.stmikjayakarta.ac.id/index.php/iisamar,

jisamar@stmikjayakarta.ac.id , jisamar2017@gmail.com

e-ISSN: 2598-8719 (Online), p-ISSN: 2598-800 ( Printed), Vol. 5 No.1 Februari 2021

yang terdaftar di Bursa Efek Indonesia (BEI) berdasarkan variabel independen Return On Equity (ROE) dan Debt to Equity Ratio (DER).

\section{Analisis Regresi Linear Berganda}

Analisis regresi linier berganda pada dasarnya adalah studi mengenai ketergantungan atau hubungan antar variabel dependen yang dalam penelitian ini yaitu Stock Return dengan satu atau lebih variabel independen yaitu Return On Equity dan Debt to Equity Ratio. Pengaruh Return On Equity dan Debt to Equity Ratio terhadap Stock Return dapat di lihat dengan menggunakan analisis regresi linier berganda dengan persamaan sebagai berikut:

\section{Tabel 5}

Hasil Analisis Regresi Linier Berganda

\section{Coefficients $^{a}$}

\begin{tabular}{|c|c|c|c|c|c|c|c|}
\hline \multirow[b]{2}{*}{ Model } & \multicolumn{2}{|c|}{$\begin{array}{l}\text { Unstandardized } \\
\text { Coefficients }\end{array}$} & \multirow{2}{*}{$\begin{array}{l}\text { Standardiz } \\
\text { ed } \\
\text { Coefficients } \\
\text { Beta }\end{array}$} & \multirow[b]{2}{*}{$\mathrm{t}$} & \multirow[b]{2}{*}{ Sig. } & \multicolumn{2}{|c|}{$\begin{array}{l}\text { Collinearity } \\
\text { Statistics }\end{array}$} \\
\hline & B & $\begin{array}{l}\text { Std. } \\
\text { Error }\end{array}$ & & & & ce $^{\text {Toleran }}$ & VIF \\
\hline $\begin{array}{ll}1 & \text { (Consta } \\
& \mathrm{nt})\end{array}$ & -.304 & .196 & & $\begin{array}{l}- \\
1.553\end{array}$ & .132 & & \\
\hline $\begin{array}{l}\text { ROE } \\
\text { (X1) }\end{array}$ & .019 & .008 & .441 & $1^{2.37}$ & .025 & .868 & $2^{1.15}$ \\
\hline $\begin{array}{l}\text { DER } \\
(\mathrm{X} 2)\end{array}$ & .214 & .132 & .302 & $4^{1.62}$ & .116 & .868 & $2^{1.15}$ \\
\hline
\end{tabular}

a. Dependent Variable: Stock Return (Y)

Sumber : Data diolah oleh caswanto, 2020 (SPSS 16).

Berdasarkan hasil pengolahan data di atas, diperoleh hasil persamaan regresi linier berganda sebagai berikut:

$$
Y=-0.304+0.019 X_{1}+0.214 X_{2}+\varepsilon
$$

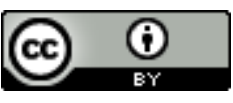

Ciptaan disebarluaskan di bawah Lisensi Creative Commons Atribusi 4.0 Internasional. 


\section{Journal of Information System, Applied, Management, Accounting and Research. http://journal.stmikjayakarta.ac.id/index.php/jisamar, jisamar@stmikjayakarta.ac.id, jisamar2017@gmail.com e-ISSN: 2598-8719 (Online), p-ISSN: 2598-800 ( Printed), Vol. 5 No.1 Februari 2021}

Dari hasil persamaan regresi linier berganda di atas, maka diperoleh hasil sebagai berikut:

1. Nilai konstanta sebesar -0.304 menunjukkan besarnya nilai dari variabel Stock Return. Apabila variabel ROE dan DER, sama dengan nol atau konstan maka akan terjadi Stock Return, yang ditunjukkan dengan nilai indeks exel yang diperoleh sebesar -0.304 yang lebih kecil dari 1. Hal tersebut menunjukkan bahwa apabila nilai ROE dan DER sama dengan nol atau konstan maka akan meningkatkan Stock Return perusahaan-perusahaan tersebut.

2. Nilai koefisien regresi untuk variabel X1 yaitu ROE bernilai positif yang berarti adanya hubungan searah antara Return On Equity (X1) dengan Stock Return (Y). Koefisien regresi variabel X1 sebesar 0.019. Berarti bahwa setiap kenaikan atau pertambahan Return On Equity (X1) sebesar satu-satuan akan menyebabkan meningkatnya Stock Return 0.019 .

Nilai koefisien regresi untuk variabel X2 yaitu Debt to Equity Ratio bernilai positif yang berarti adanya hubungan searah antara Debt to Equity Ratio (X2) dengan Stock Return (Y). Koefisien regresi variabel X2 sebesar 0.214. Berarti bahwa setiap kenaikan atau pertambahan Debt to Equity Ratio (X2) sebesar satu-satuan akan menyebabkan meningkatnya Stock Return sebesar 0.214.

Analisis Koefisien Determinasi

Koefisien Determinasi (R2) digunakan untuk mengukur seberapa jauh kemampuan variabel-variabel dependen. Nilai koefisien determinasi (R2) adalah antara nol dan satu. Nilai (R2) yang kecil berarti kemampuan variabelvariabel independen dalam menjelaskan variabel dependen amat terbatas. Jika koefisien determinasi sama dengan nol, maka variabel independen tidak berpengaruh terhadap variabel dependen. Dengan menggunakan software SPSS 16, diperoleh hasil analisis koefisien determinasi sebagai berikut :

Tabel 6

Hasil Analisis Koefisiein Determinasi

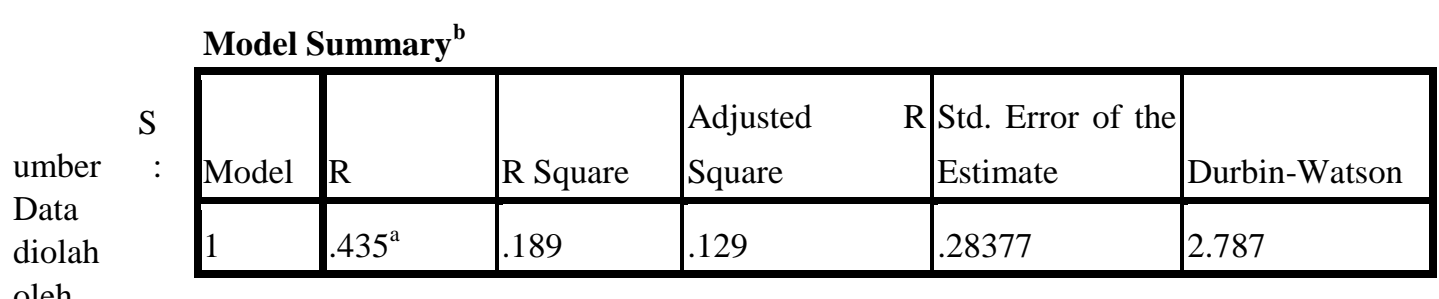

oleh a. Predictors: (Constant), DER (X2), ROE (X1)

2020 b. Dependent Variable: Stock Return (Y)

(SPSS

16).

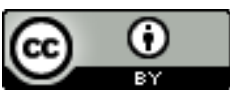

Ciptaan disebarluaskan di bawah Lisensi Creative Commons Atribusi 4.0 Internasional. 
Journal of Information System, Applied, Management, Accounting and Research.

http://journal.stmikjayakarta.ac.id/index.php/jisamar,

jisamar@stmikjayakarta.ac.id , jisamar2017@gmail.com

e-ISSN: 2598-8719 (Online), p-ISSN: 2598-800 ( Printed), Vol. 5 No.1 Februari 2021

Berdasarkan tabel 4.7 diketahui nilai koefisien determinasi ( $R$ Square) sebesar 0.435. Besarnya angka koefisien determinasi ( $R$ Square) 0.435 sama dengan $43.5 \%$. Angka tersebut mengandung arti bahwa Return On Equity (ROE) dan Debt to Equity Ratio (DER) berpengaruh terhadap Stock Return sebesar 43.5\%. Sedangkan sisanya yaitu $56.5 \%(100 \%-43.5 \%)$ dipengaruhi oleh variabel lain yang tidak diteliti dalam model regresi ini.

Hasil Uji Hipotesis

\section{Uji Parsial ( Uji t )}

Uji parsial (Uji t) digunakan untuk mengetahui pengaruh masing-masing variabel independen terhadap variabel dependen. Untuk mengetahui apakah terdapat pengaruh yang signifikan secara parsial atau individu antara variabel Retun On Equity dan Debt to Equity Ratio terhadap Stock Return dapat dilakukan dengan membandingkan $\mathrm{t}$ hitung dengan $\mathrm{t}$ tabel sesuai ketentuan sebagai berikut:

1. Jika nilai sig $<0.05$, atau $t$ hitung $>\mathrm{t}$ tabel maka terdapat pengaruh variable $\mathrm{X}$ terhadap variable $\mathrm{Y}$.

2. Jika nilai sig $>0.05$, atau $\mathrm{t}$ hitung $<\mathrm{t}$ tabel maka tidak terdapat pengaruh variable $\mathrm{X}$ terhadap variable $\mathrm{Y}$.

Hasil uji parsial (Uji t) melalui pengolahan software SPSS 16 dapat dilihat dalam tabel berikut ini :

Tabel 4. 1

\section{Coefficients $^{\mathrm{a}}$}

\begin{tabular}{|c|c|c|c|c|c|c|c|}
\hline \multirow[b]{2}{*}{ Model } & \multicolumn{2}{|c|}{$\begin{array}{l}\text { Unstandardized } \\
\text { Coefficients }\end{array}$} & \multirow{2}{*}{$\begin{array}{l}\begin{array}{r}\text { Standardize } \\
\text { d Coefficients }\end{array} \\
\text { Beta }\end{array}$} & \multirow[b]{2}{*}{$\mathrm{t}$} & \multirow[b]{2}{*}{ Sig. } & \multicolumn{2}{|c|}{$\begin{array}{l}\text { Collinearity } \\
\text { Statistics }\end{array}$} \\
\hline & B & Std. Error & & & & $\begin{array}{l}\text { Toleran } \\
\text { ce }\end{array}$ & VIF \\
\hline $\begin{array}{ll}1 & \text { (Consta } \\
& \mathrm{nt})\end{array}$ & -.304 & .196 & & -1.553 & .132 & & \\
\hline $\begin{array}{l}\text { ROE } \\
(\mathrm{X} 1)\end{array}$ & .019 & .008 & .441 & 2.371 & .025 & .868 & 1.152 \\
\hline $\begin{array}{l}\text { DER } \\
(\mathrm{X} 2)\end{array}$ & .214 & .132 & .302 & 1.624 & .116 & .868 & 1.152 \\
\hline
\end{tabular}

a. Dependent Variable: Stock Return (Y)

\section{Hasil Uji Parsial (Uji t)}

Sumber : Data diolah oleh caswanto, 2020 (SPSS 16).

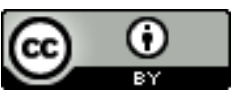

Ciptaan disebarluaskan di bawah Lisensi Creative Commons Atribusi 4.0 Internasional. 


\section{Journal of Information System, Applied, Management, Accounting and Research. http://journal.stmikjayakarta.ac.id/index.php/jisamar, jisamar@stmikjayakarta.ac.id, jisamar2017@gmail.com e-ISSN: 2598-8719 (Online), p-ISSN: 2598-800 ( Printed), Vol. 5 No.1 Februari 2021}

Berdasarkan tabel 4.8 dapat dijelaskan :

1. Pengaruh Return On Equity terhadap Stock Return

$\mathrm{H}_{1}$ : Return On Equity (ROE) berpengaruh terhadap Stock Return pada perusahaan food and beverages yang terdaftar di BEI periode 2014-2018.

Berdasarkan hasil pengujian, nilai t-hitung sebesar 2.371 dan derajat bebas (n-k-1) atau 30-2-1 = 27 diperoleh t-tabel sebesar 2.052, sehingga t-hitung > t-tabel atau 2.371 > 2.052 dan dengan nilai signifikan yang lebih besar dari 0,05 yaitu sebesar 0,025. Dengan demikian, dapat diketahui bahwa $\mathrm{H}_{0}$ ditolak dan $\mathrm{H}_{1}$ diterima, yang berarti terdapat pengaruh yang signifikan antara Return On Equity terhadap Stock Return. Hal tersebut mengindikasikan bahwa para investor mempertimbangkan efektivitas perusahaan dalam mengoptimalkan modal yang dimiliki untuk menghasilkan laba bagi perusahaan.

\section{Pengaruh Debt to Equity Ratio terhadap Stock Return}

$\mathrm{H}_{2}$ : Debt to Equity Ratio (DER) berpengaruh terhadap Stock Return pada perusahaan food and beverages yang terdaftar di BEI periode 2014-2018.

Berdasarkan hasil pengujian, nilai t-hitung sebesar 1.624 dan derajat bebas (n-k) atau 30-2 = 28 diperoleh ttabel sebesar 2.052, sehingga t-hitung < t-tabel atau $1.624<2.052$ dan dengan nilai signifikan yang lebih besar dari 0,05 yaitu sebesar 0.116. Dengan demikian, dapat diketahui bahwa $\mathrm{H}_{0}$ diterima dan $\mathrm{H}_{2}$ ditolak, yang berarti tidak terdapat pengaruh yang signifikan antara Debt to Equity Ratio terhadap Stock Return. Hal tersebut mengindikasikan bahwa para investor tidak mempertimbangkan sejauh mana penggunaan utang jika dibandingkan dengan ekuitas perusahaan.

\section{. Uji Simultan ( Uji f)}

Uji simultan (Uji F) digunakan untuk mengetahui apakah variabel independen secara bersama-sama mempengaruhi variabel dependen. Untuk mengetahui apakah Return on Equity dan Debt to Equity ratio berpengaruh secara simultan terhadap Stock Return, dapat dilakukan dengan membandingkan F hitung dengan F tabel sesuai dengan ketentuan berikut :

1. Jika nilai sig $<0.05$, atau $\mathrm{f}$ hitung $>\mathrm{f}$ tabel maka terdapat pengaruh variable $\mathrm{X}$ secara simultan terhadap variable Y.

2. Jika nilai sig $>0.05$, atau $\mathrm{f}$ hitung $<\mathrm{f}$ tabel maka tidak terdapat pengaruh variable $\mathrm{X}$ secara simultan terhadap variable $\mathrm{Y}$.

Hasil uji simultan (Uji F) melalui pengolahan software SPSS 16 dapat dilihat dalam tabel berikut ini :

Tabel 4. 2

ANOVA ${ }^{\mathbf{b}}$

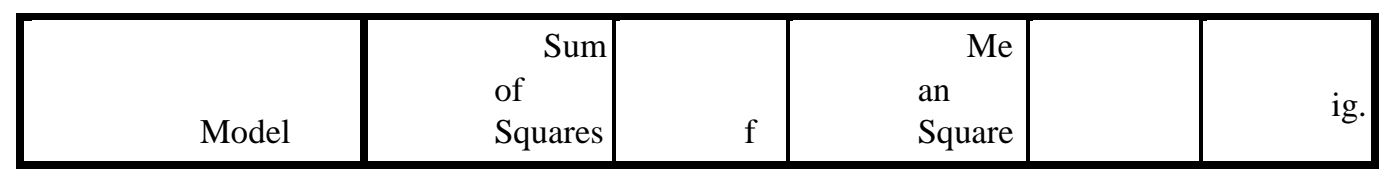

Hasil Uji Simultan (Uji F)

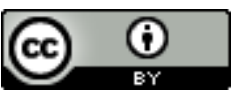

Ciptaan disebarluaskan di bawah Lisensi Creative Commons Atribusi 4.0 Internasional. 


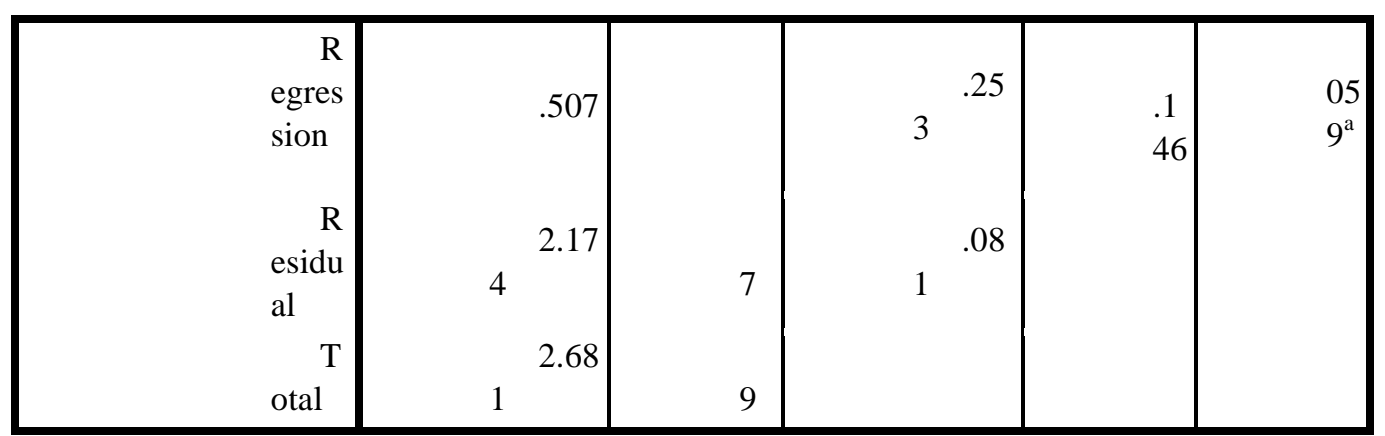

a. Predictors: (Constant), DER (X2), ROE (X1)

b. Dependent Variable: Stock Return (Y)

Sumber : Data diolah oleh caswanto, 2020 (SPSS 16).

Berdasarkan hasil dari uji F pada tabel 4.9 diketahui bahwa hasil uji F diperoleh nilai F-hitung sebesar 3.146 serta F-tabel sebesar 3.340, karena nilai F-hitung 3.146 < F-tabel 3.340 serta memiliki nilai signifikan 0.059 yang berarti lebih besar dari pada nilai $\alpha 0,05$, sehingga keputusan yang diambil adalah $\mathrm{H}_{0}$ diterima dan $\mathrm{H}_{3}$ ditolak. Dengan demikiaan dapat diketahui bahwa semua variabel independen yang terdiri dari Return On Equity dan Deb to Equity Ratio secara simultan dan signifikan tidak mempengaruhi variabel dependen yaitu Stock Return.

\section{PEMBAHASAN}

Penelitian ini bertujuan untuk mengetahui pengaruh variabel Return On Equity (ROE), dan Debt to Equity Ratio (DER) secara parsial maupun simultan terhadap Stock Return pada perusahaan food and baverage tahun 2014-2018. Berdasarkan hasil analisis, maka pembahasan mengenai hasil penelitian adalah sebagai berikut:

\section{Pengaruh Return On Equity Terhadap Stock Return}

Berdasarkan hasil penelitian menunjukkan bahwa Profitabilitas yang diukur dengan variabel Return On Equity berpengaruh positif dan signifikan terhadap Stock Return perusahaan makanan dan minuman yang terdaftar di BEI pada tahun 2014-2018. Dimana berdasarkan hasil perhitungan Uji - t terlihat bahwa variabel Return On Equity memiliki nilai t hitung sebesar 2.371 dan tingkat signifikansi sebesar $0,025<0.05$. Pengaruh Return On Equity (ROE) yang positif berbanding lurus dengan Stock Return. Hal ini mengindikasikan bahwa apabila Return On Equity mengalami peningkatan maka Stock Return akan mengalami peningkatan dan sebaliknya. Selain itu, Adanya pengaruh yang signifikan mengindikasikan bahwa besar kecilnya nilai Return On Equity akan dapat menjelaskan dan memprediksi Stock Return.

\section{Pengaruh Debt to Equity ratio Terhadap Stock Return}

Hasil penelitian tidak mendukung hipotesis ketiga bahwa Debt to Equity Ratio (DER) berpengaruh negatif dan signifikan terhadap Stock Return pada perusahaan food and beverages yang terdaftar di BEI periode 2014-2018. Hal ini ditunjukkan dengan perhitungan analisis regresi hasil pengujian menunjukkan nilai $\mathrm{t}$ hitung $1.624<\mathrm{t}$ tabel 2.052 dan nilai signifikan 0.116 yang artinya $0,116>0,05$. Hasil penelitian ini mendukung hasil dari penelitian dari (Cokorda, 2016) Debt Equity Ratio berpengaruh negatif dan tidak signifikan terhadap Stock Return.

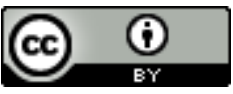

Ciptaan disebarluaskan di bawah Lisensi Creative Commons Atribusi 4.0 Internasional. 


\section{Journal of Information System, Applied, Management, Accounting and Research. http://journal.stmikjayakarta.ac.id/index.php/jisamar, jisamar@stmikjayakarta.ac.id, jisamar2017@gmail.com e-ISSN: 2598-8719 (Online), p-ISSN: 2598-800 ( Printed), Vol. 5 No.1 Februari 2021}

\section{Pengaruh Simultan Return On Equity dan Debt to Equity Ratio Terhadap Stock Return}

Berdasarkan hasil uji analisa regresi berganda pada pengujian pengaruh Return On Equity (ROE), Debt to Equity Ratio (DER) terhadap Stock Return dengan menggunakan model anova diperoleh nilai $\mathrm{F}$ hitung $<\mathrm{F}$ tabel $(3.15<3.34)$ dengan nilai probabilitas (signifikansi) $0.059>0,05$. Hal ini menunjukkan bahwa variabel Return On Equity (ROE) dan Debt to Equity Ratio (DER) secara simultan tidak berpengaruh terhadap Stock Return pada perusahaan Food and Beverage di Indonesia pada tahun 2014-2018.

\section{KESIMPULAN}

Penelitian ini menguji pengaruh Return On Equity (ROE), dan Debt to Equity Ratio (DER) terhadap Stock Return pada perusahaan food and baverages yang terdaftar di Bursa Efek Indonesia periode 2014-2018. Berdasarkan hasil penelitian dan pembahasan yang telah diuraikan, dapat ditarik kesimpulan sebagai berikut:

1. Return On Equity (ROE) berpengaruh positif dan signifikan terhadap Stock Return pada perusahaan food and baverages yang terdaftar di Bursa Efek Indonesia periode 2014-2018. Return On Equity (ROE) yang tinggi memilki arti bahwa perusahaan memaksimalkan ekuitasnya secara efektif dan efisien, Sebaliknya Return On Equity (ROE) yang rendah menunjukkan perusahaan tidak efektif dan efisien dalam memaksimalkan ekuitasnya. Semakin tinggi Return On Equty (ROE) memperlihatkan perusahaan berhasil dalam mengelola maupun memberdayakan ekuitasnya untuk menghasilkan laba. Sehubungan hal tersebut akan memberikan dampak positif bagi investor yaitu membuat nilai tambah daya tarik investor untuk mengivenstasikan dananya dalam perusahaan.

2. Debt to Equity Ratio (DER) berpengaruh negatif dan tidak signifikan terhadap Stock Return pada perusahaan food and baverages yang terdaftar di Bursa Efek Indonesia periode 2014-2018. Semakin besar Debt to Equity Ratio (DER) memperlihatkan struktur modal yang berasal dari utang untuk memenuhi ekuitas. Sebaliknya apabila Debt to Equity Ratio (DER) memiliki nilai yang rendah akan semakin baik. Tingginya DER akan memiliki dampak negatif antara dari sisi kreditur akan menilai bahwa risiko atas kegagalan membayar utang mungkin terjadi perusahaan juga akan semakin besar, dari sisi investor akan mengartikan untuk memenuhi kegiatan operasional perusahaan dari pinjaman atau utang lebih besar akan memperlihatkan kinerja perusahaan tidak baik, maka Stock Return akan menurun, sehingga Debt to Equity Ratio (DER) berpengaruh negatif terhadap Stock Return.

3. Return On Equity (ROE) dan Debt to Equity ratio (DER) tidak berpengaruh secara simultan dan signifikan terhadap Stock Return pada perusahaan. Hal ini menunjukkan bahwa variabel Return On Equity (ROE) dan Debt to Equity Ratio (DER) secara simultan tidak berpengaruh terhadap Stock Return pada perusahaan Food and Beverage di Indonesia pada tahun 2014-2018.

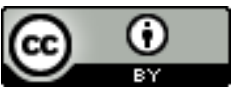

Ciptaan disebarluaskan di bawah Lisensi Creative Commons Atribusi 4.0 Internasional. 
Journal of Information System, Applied, Management, Accounting and Research.

http://journal.stmikjayakarta.ac.id/index.php/iisamar,

jisamar@stmikjayakarta.ac.id, jisamar2017@gmail.com

e-ISSN: 2598-8719 (Online), p-ISSN: 2598-800 ( Printed), Vol. 5 No.1 Februari 2021

\section{REFERENASI}

[1] N. F. Arifin and S. Agustami, "PENGARUH LIKUIDITAS, SOLVABILITAS, PROFITABILITAS, RASIO PASAR, DAN UKURAN PERUSAHAAN TERHADAP HARGA SAHAM (Studi Pada Perusahaan Subsektor Perkebunan yang Terdaftar Di Bursa Efek Indonesia Tahun 2010-2014)," J. Ris. Akunt. Dan Keuang., vol. 4, no. 3, pp. 1189-1210, Desember 2016, doi: https://doi.org/10.17509/jrak.v4i3.4673.

[2] M. M. Hanafi, Analisis Laporan Keuangan, 5th ed. Yogyakarta: UPP STIM YKPN, 2016.

[3] I. Nurmasari, “ANALISIS CURRENT RATIO, RETURN ON EQUITY, DEBT TO EQUITY RATIO DAN PERTUMBUHAN PENDAPATAN BERPENGARUH TERHADAP RETURN SAHAM PADA PERUSAHAAN PERTAMBANGAN DI BURSA EFEK INDONESIA 2010-2014,” Kreatif, vol. 5, no. 1, pp. 112131, 2017, doi: http://dx.doi.org/10.32493/jk.v5i1.y2017.p112-131.

[4] C. E. Kampongsina, S. Murni, and V. N. Untu, "PENGARUH CURRENT RATIO, DEBT TO EQUITY DAN RETURN ON EQUITY TERHADAP RETURN SAHAM PADA PERUSAHAAN FARMASI YANG TERDAFTAR DI BEI (PERIODE 2015-2019)," J. Emba J. Ekon. Manaj. Bisnis Dan Akunt., vol. 8, no. 4, doi: https://doi.org/10.35794/emba.v8i4.31230.

[5] Wiratno, "BEI Cermati Pergerakan Liar ALTO Oleh Warta Ekonomi Online," 2017.

https://id.investing.com/news/stock-market-news/bei-cermati-pergerakan-liar-alto-370033 (accessed Jan. 17, 2021).

[6] I. Fahmi, Analisis Laporan Keuangan, 7th ed. Bandung: Alfabeta, 2020.

[7] V. Rika, "FAKTOR-FAKTOR PENENTU YANG MEMPENGARUHI RETURN SAHAM PERUSAHAAN MANUFAKTUR YANG TERDAFTAR DI BURSA EFEK INDONESIA (BEI) PERIODE 20082013.," Thesis, Universitas Negeri Yogyakarta, Yogyakarta, 2019.

[8] zubir, Managemen Portofolio: Penerapannya dalam Investasi Saham. Jakarta Selatan: Salemba Empat, 2011.

[9] E. Tandelilin, Analisis investasi dan manajemen portofolio. Yogyakarta: BPFE, 2001.

[10] J. Hartono, Teori Portofolio dan Analisis Investasi, 11th ed. Yogyakarta: BPFE, 2017.

[11] Kasmir, Analisis Laporan Keuangan, 11th ed. Depok: RajaGrafindo Persada, 2018.

[12] S. Riyadi, Banking assets and liability management, 2nd ed. Jakarta: Lembaga Penerbit Fakultas Ekonomi Universitas Indonesia, 2004.

[13] A. Sawir, Analisis Kinerja Keuangan dan Perencanaan Keuangan Perusahaan. Jakarta: Gramedia Pustaka Utama, 2001.

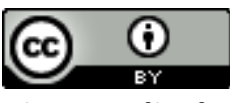

Ciptaan disebarluaskan di bawah Lisensi Creative Commons Atribusi 4.0 Internasional. 


\section{Journal of Information System, Applied, Management, Accounting and Research. \\ http://journal.stmikjayakarta.ac.id/index.php/iisamar, jisamar@stmikjayakarta.ac.id , jisamar2017@gmail.com e-ISSN: 2598-8719 (Online), p-ISSN: 2598-800 ( Printed), Vol. 5 No.1 Februari 2021}

[14] Prof. Dr. Sugiyono, Metode Penelitian Kuantitatif, Kualitatif, dan R\&D, 2nd ed. Bandung: CV Alfabeta, 2019.

[15] Trijono, Metodologi Penelitian Kuantitatif. Depok: Papas Sinar Sinanti, 2015.

[16] R. G. Sudarmanto, Statistik Terapan Berbassis Komputer dengan Program IBM SPPS Statistics 19, 1st ed. Bogor: PT Mitra Wacana Media, 2013.

[17] I. Ghozali, Aplikasi Analisis Multivariate dengan SPSS., 5th ed. Semarang: Badan Penerbit Undip, 2012.

[18] U. Sekaran and R. Bougie, Metode Peneleitian untuk Bisnis, 6th ed. Jakarta Selatan: Salemba Empat, 2017.

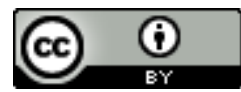

Ciptaan disebarluaskan di bawah Lisensi Creative Commons Atribusi 4.0 Internasional. 